\title{
Podocytic infolding in Schimke immuno- osseous dysplasia with novel SMARCAL1 mutations: a case report
}

\author{
Shiqiu Xiong ${ }^{\dagger}$, Lanjun Shuai ${ }^{\dagger}$, Xiaoyan Li, Xiqiang Dang, Xiaochuan Wu ${ }^{*}$ and Qingnan $\mathrm{He}^{*}$
}

\begin{abstract}
Background: Schimke immuno-osseous dysplasia (SIOD) is a rare autosomal recessive disorder characterized by spondyloepiphyseal dysplasia, progressive renal insufficiency and defective cellular immunity. Podocytic infolding glomerulopathy (PIG) is a newly proposed disease entity characterized by microspheres or microtubular structures associated with podocytes infolding into the glomerular basement membrane (GBM) on electron microscopy (EM).

Case presentation: A 4-year-old boy was admitted to our ward due to proteinuria and edema lasting 1 month. He had a short trunk and demonstrated subtle dysmorphology, with a triangular shape, a broad nasal bridge and a bulbous nasal tip. The laboratory findings were as follows: lymphocytes, $0.5 \times 10^{9} / \mathrm{L}$; urine protein, $3.67 \mathrm{~g} / \mathrm{d}$; albumin, $9.8 \mathrm{~g} / \mathrm{L}$; and cholesterol, $11.72 \mathrm{mmol} / \mathrm{L}$. Skeletal $X$ rays showed small iliac wings, small ossification centers of the capital femoral epiphyses, shallow dysplastic acetabular fossae and mildly flattened vertebrae. The specimen for light microscopy (LM) suggested focal segmental glomerulosclerosis (FSGS). EM revealed a focal thickness of the GBM with some cytoplasmic processes of podocyte infolding into the GBM. Gene sequencing showed novel compound heterozygous mutations in the SMARCAL1 gene (c.2141+5G>A; c.2528 + 1G > A) that were inherited from his parents. Finally, we established the diagnosis of SIOD and treated him with diuretics and angiotensinconverting enzyme inhibitors (ACEls).
\end{abstract}

Conclusion: The pathogenic mechanism of PIG has not been clarified. Further studies are required to understand whether gene mutations, especially those related to podocytes, contribute to the pathogenesis of podocytic infolding.

Keywords: Schimke immuno-osseous dysplasia, Podocytic infolding glomerulopathy, Nephrotic syndrome

\section{Background}

Schimke immuno-osseous dysplasia (SIOD) is an autosomal recessive inherited disease in which the SMARCAL1 gene is mutated on chromosome 2; SIOD is mainly characterized by spondyloepiphyseal dysplasia, lymphopenia with defective cellular immunity, and progressive renal dysfunction [1]. Hypothyroidism, bone marrow failure, and episodic cerebral ischemia have also

\footnotetext{
*Correspondence: xiaochuanwu@csu.edu.cn; hegn2629@csu.edu.cn Shiqiu Xiong and Lanjun Shuai are Co-first author Department of Pediatrics, the Second Xiangya Hospital, Central South University, Changsha 410011, Hunan, China
}

been reported [2]. Patients with SIOD are resistant to various immunosuppressants. Histopathology of the kidney in most of the patients shows FSGS [2]. PIG is a rare and peculiar glomerulopathy in which the ultrastructural finding shows podocyte infolding and invagination into the GBMs, characterized by microspherules and microtubules on EM [3]. Only 31 cases have been reported worldwide to date, and almost two-thirds of the patients were diagnosed with connective tissue disease [4]. To date, no case of SIOD has been reported in which kidney histopathology indicates podocytic infolding.

(c) The Author(s). 2020 Open Access This article is licensed under a Creative Commons Attribution 4.0 International License, which permits use, sharing, adaptation, distribution and reproduction in any medium or format, as long as you give appropriate credit to the original author(s) and the source, provide a link to the Creative Commons licence, and indicate if changes were made. The images or other third party material in this article are included in the article's Creative Commons licence, unless indicated otherwise in a credit line to the material. If material is not included in the article's Creative Commons licence and your intended use is not permitted by statutory regulation or exceeds the permitted use, you will need to obtain permission directly from the copyright holder. To view a copy of this licence, visit http://creativecommons.org/licenses/by/4.0/ The Creative Commons Public Domain Dedication waiver (http://creativecommons.org/publicdomain/zero/1.0/) applies to the data made available in this article, unless otherwise stated in a credit line to the data. 


\section{Case presentation}

The 4-year-old boy was the third child of nonconsanguineous parents and was admitted to our ward in February 2019 for proteinuria and edema lasting 1 month. Both his parents and two older sisters were healthy and had normal stature, and his two brothers were stillborn of unknown cause. He was born at 34 weeks of gestation with a 1-kg birth weight and presented growth retardation. He had a short trunk with a height of $81 \mathrm{~cm}$ and a weight of $9.5 \mathrm{~kg}$. The boy demonstrated subtle dysmorphology, with a triangular shape, a broad nasal bridge and a bulbous nasal tip. He had swollen eyelids, lumbar lordosis and a protruding abdomen (Fig. 1). The shifting dullness was negative, and his bilateral lower limbs were swollen. In our department, the laboratory findings were as follows: lymphocytes, $0.5 \times 10^{9} / \mathrm{L}$; urine protein, $3.67 \mathrm{~g} / \mathrm{d}(0-0.15 \mathrm{~g} / \mathrm{d})$; urine protein/creatinine, $20.1 \mathrm{~g} / \mathrm{g}(0-0.2 \mathrm{~g} / \mathrm{g})$; albumin, $9.8 \mathrm{~g} /$ $\mathrm{L}(40.0 \mathrm{~g} / \mathrm{L}-55.0 \mathrm{~g} / \mathrm{L}) ;$ cholesterol, $11.72 \mathrm{mmol} / \mathrm{L}(2.9$ $\mathrm{mmol} / \mathrm{L}-5.20 \mathrm{mmol} / \mathrm{L}) ; \mathrm{FT} 3,0.73 \mathrm{pg} / \mathrm{ml}(2.00 \mathrm{pg} / \mathrm{ml} \mathrm{-}$ $4.40 \mathrm{pg} / \mathrm{ml}) ; \quad$ FT4, $\quad 0.58 \mathrm{ng} / \mathrm{dl} \quad(0.93 \mathrm{ng} / \mathrm{dl}-1.70 \mathrm{ng} / \mathrm{dl})$; and TSH, $10.85 \mu \mathrm{IU} / \mathrm{ml}(0.27 \mu \mathrm{IU} / \mathrm{ml}-4.20 \mu \mathrm{IU} / \mathrm{ml})$. The flow cytometry results were as follows: CD3+, $137 / \mu \mathrm{L} ; \quad \mathrm{CD} 3+\mathrm{CD} 4+, \quad 79 / \mu \mathrm{L} ; \quad \mathrm{CD} 3+\mathrm{CD} 8+, \quad 7 / \mu \mathrm{L} ;$ CD4+/CD8+, 1.54; CD3-CD19+, 405/ $\mu \mathrm{L}$; and CD3CD16/CD56+, 176/ $\mu \mathrm{L}$. He had no hepatitis infection, and the markers of autoimmunity (ANA, ANCA, dsDNA) were negative. Skeletal $\mathrm{X}$ rays showed small iliac wings, small ossification centers of the capital femoral epiphyses, shallow dysplastic acetabular fossae and mildly flattened vertebrae (Fig. 2). He was diagnosed with nephrotic syndrome and hypothyroidism, received 6 weeks of prednisone $(17.5 \mathrm{mg} / \mathrm{d})$ and pulse steroid therapy with $100 \mathrm{mg}$ methyl prednisolone for
3 days, and was then started on a combined therapy of steroids and tacrolimus. However, his proteinuria did not improve. During hospitalization, he had influenza $A$, severe bacterial pneumonia and fungal infection. Because of his special phenotype and resistance to multiple immunosuppressants, a kidney biopsy and gene sequencing were performed. The specimen for LM included twenty-one glomeruli, seven of which exhibited global or focal sclerosis, and some glomeruli were poorly developed (Fig. 3). The deposition of IgA, IgG, IgM, C1q, C3, and C4 by immunofluorescent study (IF) was negative. EM revealed a focal thickness of the GBM $(500-2000 \mathrm{~nm}$ in thickness) without electron-dense deposits. The foot process of podocyte effacement was extensive, with some cytoplasmic processes infolding into the GBM (Fig. 3). Whole exome sequencing showed novel compound heterozygous mutations in the SMARCAL1 gene (NM_001127207), [5]. Two mutations (c. $2141+5 \mathrm{G}>\mathrm{A} ; \quad$ c. $2528+1 \mathrm{G}>\mathrm{A})$ were inherited from his parents (Fig. 4). The c.2141+ $5 \mathrm{G}>\mathrm{A}$ mutation was confirmed to create a novel splice donor site [6]. The c. $2528+1 \mathrm{G}>\mathrm{A}$ mutation was not observed in the gnomAD database. According to the ACMG guidelines [7], the c. $2528+1 \mathrm{G}>\mathrm{A}$ mutation was classified as likely pathogenic. According to the clinical manifestations and pedigree analysis, we established the diagnosis of SIOD. Given the resistance to steroids and tacrolimus, we stopped these drugs gradually and only treated him with diuretics and angiotensin-converting enzyme inhibitors (ACEIs). After treatment, his edema disappeared gradually, and he was discharged 2 months later. We followed up until June 2019, and the boy did not have edema again and had normal renal function.

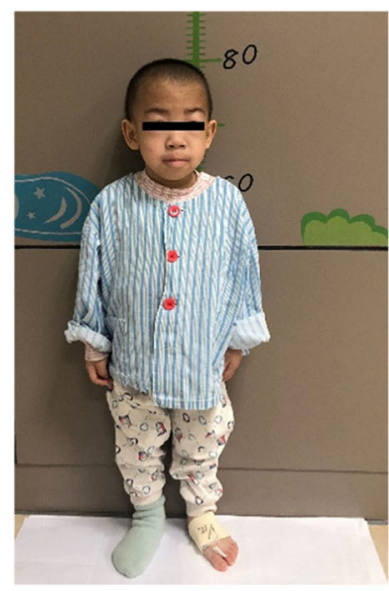

a

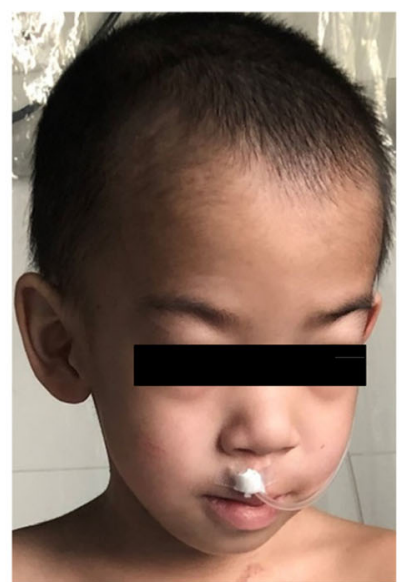

b

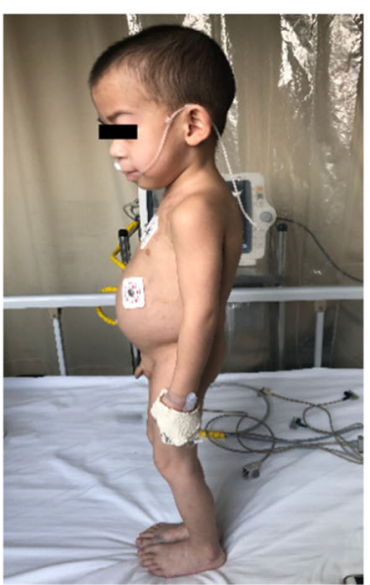

C

Fig. 1 The patient had a short trunk with a height of $81 \mathrm{~cm}(\mathbf{a})$, and demonstrated subtle dysmorphology, with a triangular shape, a broad nasal bridge and a bulbous nasal tip (b). He had lumbar lordosis and a protruding abdomen (c) 


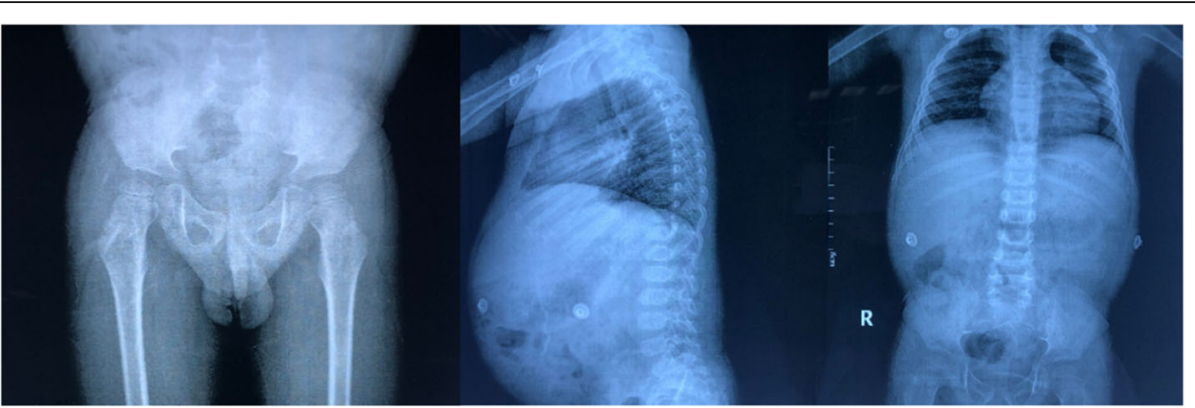

Fig. 2 Skeletal $X$ rays show small iliac wings, small ossification centers of the capital femoral epiphyses, shallow dysplastic acetabular fossae and mildly flattened vertebrae

\section{Discussion and conclusions}

To date, the pathogenic mechanism of PIG has not been clarified. As almost all the patients with PIG were from East Asia, ethnic or genetic factors might play a role [4]. PIG occurred in most of the patients with underlying immune disorders. Moreover, renal function and proteinuria could be improved by immunosuppressive therapy, supporting the hypothesis of immune abnormalities [8]. Since C5b-9 formation was found by immunoelectron microscopy, some researchers proposed that special types of complements might activate podocytes to infold their process into the GBM, but no autoimmune disorders or abnormal levels of complements were detected in many patients by routine laboratory examinations, and not all biopsies of patients revealed complementary immunoglobulins on LM, indicating that other factors might be involved in the mechanism $[9,10]$. GBM materials such as type IV collagen, laminin and heparin sulfate are made mainly by

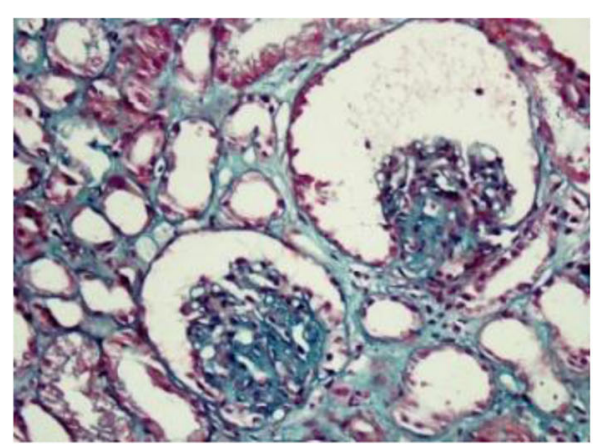

a

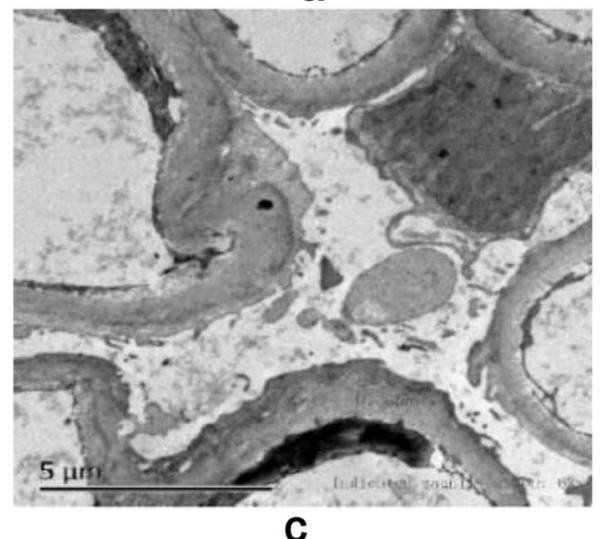

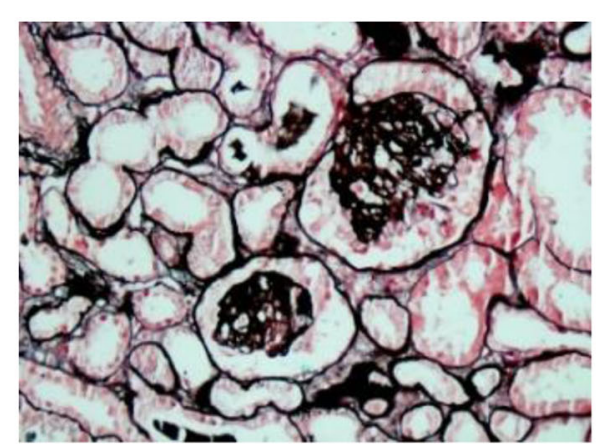

b

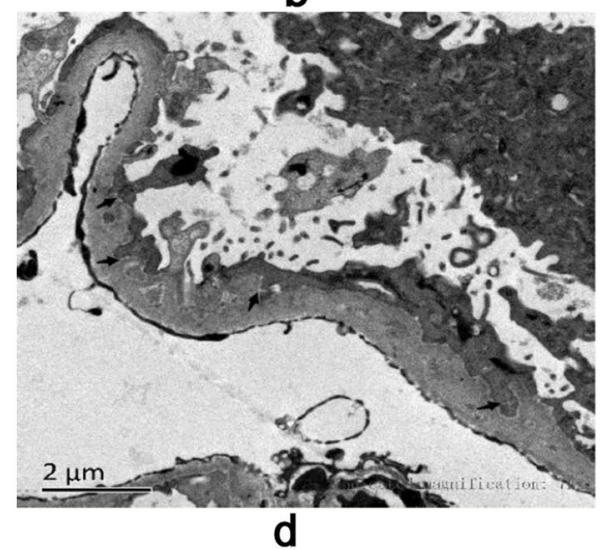

Fig. 3 LM shows a glomerulus with segmental sclerosis (a and $\mathbf{b}$ ). EM reveals a focal thickness of the GBM without electron-dense deposits. The foot process of podocyte effacement is extensive, with some cytoplasmic processes infolding into the GBM (arrows) (c and $\mathbf{d}$ ) 


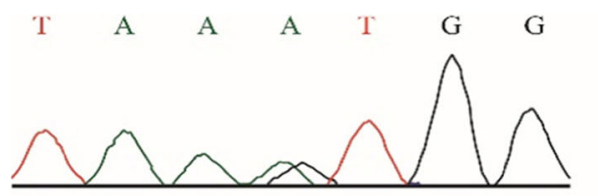

a

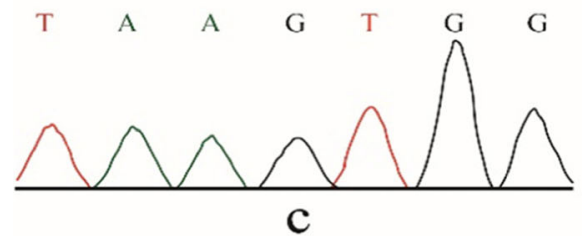

c

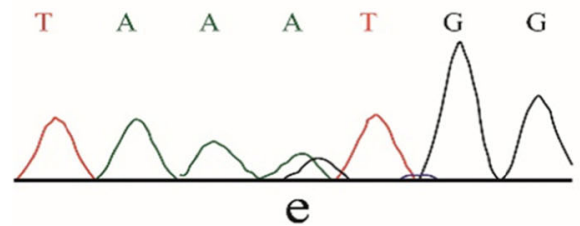

$\begin{array}{llllllllll}\text { T } & \text { T } & \text { G } & \text { A } & \text { T } & \text { A } & \text { I }\end{array}$

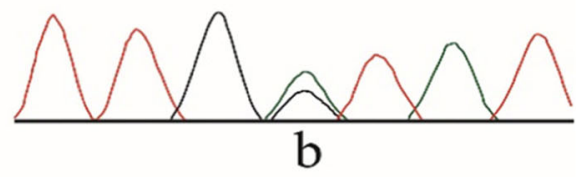

$\begin{array}{lllllll}\text { T } & \text { T } & \text { G } & \text { A } & \text { T } & \text { A } & \text { T }\end{array}$
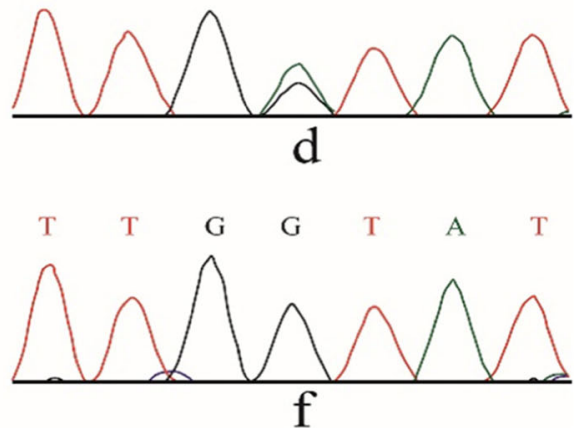

Fig. 4 Genetic analysis of the family. Mutation analysis: the patient carries two mutations of the SMARCAL1 gene (a and $\mathbf{b})$, his mother carries the c. $2528+1 G>$ A mutation (c and $\mathbf{d}$ ), his father carries the c. $2141+5 G>$ A mutation (e and $\mathbf{f}$ )

podocytes, and the imbalance between synthesizing and degrading these materials may lead to dysfunction of the GBM, which may trap the foot process more easily $[11,12]$. PIG was also found in our patient with mutations in the SMARCAL1 gene. Within the glomerulus, SMARCAL1 localizes to podocytes and endothelial cells, which play a role in the maintenance and integrity of these cells [13]. Further studies are required to understand whether gene mutations, especially those related to podocytes, contribute to the pathogenesis of podocytic infolding.

\section{Abbreviations}

SIOD: Schimke immuno-osseous dysplasia; PIG: Podocytic infolding glomerulopathy; GBM: Glomerular basement membrane; EM: Electron microscopy; LM: Light microscopy; FSGS: Focal segmental glomerulosclerosis; ACEls: Angiotensin-converting enzyme inhibitors

\section{Acknowledgements}

Not applicable.

\section{Authors' contributions}

SQX was the second-year resident and wrote the paper; LJS and XYL were the attending physicians that participated in the care of the patient; XQD performed the histological examination of the kidney; XCW and QNH analyzed and interpreted the patient's data. All authors read and approved the final manuscript.

\section{Funding}

Not applicable.

\section{Availability of data and materials}

The datasets used and/or analysed during the current study are available.

\section{Ethics approval and consent to participate}

This manuscript granted an exemption from requiring ethics approval by the Ethics Review Committee of the Second Xiangya Hospital of Central South University.

Consent to publication: Written consent was obtained from the patient's family for the publication of the case report and its accompanying images.

\section{Competing interests}

The authors declare that they have no competing interests.

Received: 28 October 2019 Accepted: 15 April 2020

Published online: 11 May 2020

\section{References}

1. Saraiva JM, Dinis A, Resende C, Faria E, Gomes C, Correia AJ, et al. Schimke immune-osseous dysplasia: case report and review of 25 patients. J Med Genet. 1999;36:786-9.

2. Boerkoel CF, O’Neill S, André JL, Benke PJ, Bogdanovíć R, Bulla M, et al. Manifestations and treatment of Schimke immuno-osseous dysplasia: 14 new cases and a review of the literature. Eur J Pediatr. 2002;159:1-7.

3. Joh K, Taguchi T, Shigematsu H, Kobayashi Y, Sato H, Nishi S, et al. Proposal of podocytic infolding glomerulopathy as a new disease entity: a review of 25 cases from nationwide research in Japan. Clin Exp Nephrol. 2008;12:42131.

4. Zhang T, Sun W, Xue J, Chen J, Jiang Q, Mou L, et al. Podocytic infolding glomerulopathy: two new cases with connective tissue disease and literature review. Clin Rheumatol. 2019;38:1521-8.

5. O'Leary NA, Wright MW, Brister JR, Ciufo S, Haddad D, McVeigh R, et al. Reference sequence (RefSeq) database at NCBI: current status, taxonomic expansion, and functional annotation. Nucleic Acids Res. 2016;44:D733-45.

6. Jin J, Wu K, Liu Z, Chen X, Jiang S, Wang Z, et al. Whole exome sequencing identified a novel biallelic SMARCAL1 mutation in the extremely rare disease SIOD. Front Genet. 2019;10:565.

7. Richards S, Aziz N, Bale S, Bick D, Das S, Gastier-Foster J, et al. Standards and guidelines for the interpretation of sequence variants: a joint consensus recommendation of the American College of Medical Genetics and Genomics and the Association for Molecular Pathology. Genet Med. 2015; 17:405-24.

8. Matthai SM, Mohapatra A, Mathew AJ, Roy S, Varughese S, Danda D, et al. Podocyte infolding glomerulopathy (PIG) in a patient with undifferentiated connective tissue disease: a case report. Am J Kidney Dis. 2018;72:149-53.

9. Fujigaki Y, Muranaka Y, Sakakima M, Ohta I, Sakao Y, Fujikura T, et al. Analysis of intra-GBM microstructures in a SLE case with glomerulopathy associated with podocytic infolding. Clin Exp Nephrol. 2008;12:432-9.

10. Iguchi A, Sohma A, Yamazaki H, Ito T, Saeki T, Ito Y, et al. A case of podocytic infolding glomerulopathy with focal segmental glomerulosclerosis. Case Rep Nephrol Urol. 2013;3:110-6.

11. Miura N, Mori Y, Yoshino M, Suga N, Kitagawa W, Yamada H, et al. Membranous nephropathy (bubbling appearance and spike formation) 
without immunoglobulin deposition in a patient with systemic lupus erythematosus. Clin Exp Nephrol. 2008;12:475-8.

12. Nomura S, Inoue-Kiyohara M, Oosugi K, Ishikawa E, Obe T, Horiki T, et al. Unusual glomerulopathy with aggregated subepithelial microspheric particles resembling membranous nephropathy: a variant of glomerulopathy associated with podocytic infolding? Clin Exp Nephrol. 2008;12:513-7.

13. Sarin S, Javidan A, Boivin F, Alexopoulou I, Lukic D, Svajger B, et al. Insights into the renal pathogenesis in Schimke Immuno-osseous dysplasia: a renal histological characterization and expression analysis. J Histochem Cytochem. 2015;63:32-4.

\section{Publisher's Note}

Springer Nature remains neutral with regard to jurisdictional claims in published maps and institutional affiliations.

Ready to submit your research? Choose BMC and benefit from:

- fast, convenient online submission

- thorough peer review by experienced researchers in your field

- rapid publication on acceptance

- support for research data, including large and complex data types

- gold Open Access which fosters wider collaboration and increased citations

- maximum visibility for your research: over $100 \mathrm{M}$ website views per year

At BMC, research is always in progress.

Learn more biomedcentral.com/submissions 